Notebooks: The Journal for Studies on Power 


\section{Notebooks: The Journal for Studies on Power}

\section{Editors in Chief}

Francesca Congiu, University of Cagliari, Italy

Margherita Sabrina Perra, University of Cagliari, Italy

Editorial Operations Manager

Michela Cerimele, Italy

Book Review Editor

Francesco Pontarelli, University of Johannesburg, South Africa

Editorial Board

Stefano Bellucci, Leiden University and International Institute of Social History, The Netherlands

Marcos Aurelio Da Silva, Universidade Federal de Santa Catarina, Brazil

Marcus E. Green, Pasadena City College, USA

Praveen Jha, Jawaharlal Nehru University, India

Rebecca Karl, New York University, USA

Federico Losurdo, University of Urbino, Italy

Elisabeth Perry, Harvard University, USA

Juan Pablo Scarfi, Universidad Nacional de San Martin, Argentina

Marina Terkourafi, Leiden University, The Netherlands

Peter Thomas, Brunel University, UK

\section{Advisory Board}

Gilbert Achcar, SOAS University of London, UK

Lucio Baccaro, Max Planck Institute for the Study of Societies - Director, Germany

Gonzalo Maestro Buelga, University of the Basque Country - Bilbao, Spain

Antonio Cantaro, University of Urbino, Italy

Fabio Frosini, University of Urbino, Italy

Biyan Ghebreyesus, Eritrea Institute of Technology, Eritrea

Kevin Gray, University of Sussex, UK

Fabio Lanza, The University of Arizona, USA

Marcel van der Linden, University of Amsterdam (emeritus) and International Institute of Social History, The Netherlands

Alessandra Mezzadri, SOAS University of London, UK

Alfredo Saad-Filho, King's College London, UK

Donald Sassoon, Queen Mary University of London (emeritus) UK

Wang Hui, Tsinghua University, China

Volumes published in this journal are listed at brill.com/powr 


\section{Notebooks: The Journal for Studies on Power}

VOLUME 1 (2021)

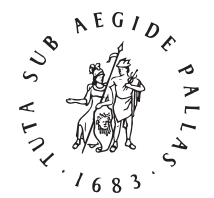

B R I L L

LEIDEN | BOSTON 
Notebooks uses Editorial Manager, a web-based submission and peer review tracking system. All manuscripts should therefore be submitted online at editorialmanager.com/powr. Please make sure to consult the Instructions for Authors prior to submission to ensure your submission is formatted correctly. For any questions, please contact the Editorial Office at notebooks@unica.it.

Brill Open Access options can be found at brill.com/brillopen.

Typeface for the Latin, Greek, and Cyrillic scripts: "Brill”. See and download: brill.com/brill-typeface.

ISSN 2666-7177

E-ISSN 2666-7185

Copyright 2021 by Koninklijke Brill NV, Leiden, The Netherlands.

Koninklijke Brill NV incorporates the imprints Brill, Brill Nijhoff, Brill Hotei, Brill Schöningh, Brill Fink, Brill mentis, Vandenhoeck \& Ruprecht, Böhlau Verlag and V\&R Unipress.

All rights reserved. No part of this publication may be reproduced, translated, stored in retrieval system, or transmitted in any form or by any means, electronic, mechanical, photocopying, recording or otherwise, without prior written permission from the publisher. Requests for re-use and/or translations must be addressed to Koninklijke Brill NV via brill.com or copyright.com.

Brill has made all reasonable efforts to trace all rights holders to any copyrighted material used in this work. In cases where these efforts have not been successful the publisher welcomes communications from copyright holders, so that the appropriate acknowledgements can be made in future editions, and to settle other permission matters.

This journal is printed on acid-free paper and produced in a sustainable manner. 